\title{
PEMANFAATAN TEKNOLOGI UNTUK MENDUKUNG KESEJAHTERAAN KELUARGA DENGAN BERWIRAUSAHA
}

\author{
Julian Maradina ${ }^{1}$, Yunita Kurnia Shanti ${ }^{2}$, Luh Nadi ${ }^{3}$, Susi Sih Kusumawardhany ${ }^{4}$, Riska \\ Damayanti $^{5}$
}

S-1 Akuntansi, Ekonomi, Universitas Pamulang

Korespondensi penulis : jmaradina@yahoo.co.id

\begin{abstract}
Abstrak
Perkembangan pertumbuhan teknologi saat ini telah berkembang dengan pesatnya, salah satunya munculnya adanya fintech. Fintech merupakan inovasi yang berkembang dalam pengadaptasian di dalam jaringan komputer yang diterapkannya pada bidang keuangan. Kendala yang terjadi pada saat pemanfaatan teknologi adalah kurangnya maksimal dalam penggunaan pemanfaatan teknologi untuk berwirausaha dan juga kurangnya mengenal teknologi itu sendiri. Dalam hal ini pelaku berwirausaha termasuk Ibu-ibu Rumah Tangga banyak yang kurang memahami aplikasi dan pengetahuan mengenai teknologi. Maka Pengabdian Kepada Masyarakat ini dilakuan bertujuan untuk memberikan pemahaman kepada para Ibu-ibu Rumah Tangga tentang pemanfaatan teknologi sebagai instrumen untuk dapat berwirausaha dengan memanfaatkan teknologi yang canggih dan untuk dapat menuju keluarga sejahtera. Dalam Pengabdian Kepada Masyarakat metode yang digunakan dalam penyampaian materi yaitu dengan cara mempersentasikan materi dan sesi tanya jawab. Dan hasil yang didapat dalam Pengabdian Kepada Masyarakat adalah Ibu-ibu Rumah tangga mengetahui dan paham terhadap pemanfaatan teknologi untuk mendukung kesejahteraan keluarga dengan berwirausaha menjadi terbuka dan paham akan kemajuan teknologi dapat menjembatani para Ibu-ibu Rumah tangga dalam berwirausaha. Kesimpulan dari kegiatan Pengabdian Kepada Masyarakat kali ini bahwa dalam teknologi banyak membawa manfaat terutama dalam berwirausaha. Saran, diharapkan kegiatan Pengabdian Kepada Masyarakat ini dapat berkelanjutan dan lebih luas lagi cakupannya.
\end{abstract}

Kata-kata kunci: Teknologi; Fintech; Berwirausaha

\begin{tabular}{l} 
Abstract \\
\hline The development of technological growth at this time has been developing rapidly, \\
one of which is the emergence of fintech. Fintech is a developing innovation in \\
adaptation in computer networks that is applied in the financial sector. The obstacles \\
that occur when utilizing technology are the maximum lack of use of technology for \\
entrepreneurship and also the lack of knowing the technology itself. In this case, many \\
entrepreneurs including housewives who do not understand the application and \\
knowledge of technology. So this Community Service is aimed at providing \\
understanding to Housewives about the use of technology as an instrument for \\
entrepreneurship by utilizing sophisticated technology and to be able to lead a \\
prosperous family. In Community Service the method used in the delivery of material is \\
to present the material and question and answer session. And the results obtained in \\
Community Service are housewives who know and understand the use of technology to \\
support family welfare by becoming open entrepreneurs and understanding of
\end{tabular}


technological advances can bridge the housewives in entrepreneurship. The conclusion from the Community Service activities this time is that there are many benefits in technology, especially in entrepreneurship. Suggestions, it is hoped that this Community Service activity will be sustainable and broader in scope.

Keywords: Technology; Fintech; Entrepreneurship

\section{PENDAHULUAN}

Sebagai salah satu bentuk penerapan teknologi informasi di bidang keuangan. Fintech memiliki fungsi beragam, yang diyakini mampu dengan cepat berkembang secara cepat. Saat ini fintech mampu melayani electronic money, virtual account, agregator, lending, crowdfunding dan transaksi keuangan online lainnya. Adapun fintech yang telah beroperasi, sebagian ada yang didirikan oleh perusahaan berbasis konvensional, tetapi tidak sedikit pula yang merupakan perusahaan rintisan atau startup. Namun perkembangan fintech di Indonesia tetap berada dalam pengawasan Bank Indonesia (BI) selaku bank sentral. Inovasi yang berkembang di sini adalah pengadaptasian prinsip jaringan komputer yang diterapkan pada bidang keuangan. Meski pada mulanya konsep finansial Peer to Peer ini diperuntukkan bagi para start-up (wirausaha baru) dalam mencari investor untuk membiayai bisnisnya, namun dalam perkembangannya finansial Peer to Peer ini telah menjadi crowdfunding, sehingga pemanfaatan finansial Peer to Peer ini tidak terbatas bagi para start-up saja. Dengan munculnya virus inovasi keuangan P2P yang berbasis jaringan Internet maka tentunya penyebarannya menjadi sangat cepat secara global hingga pada akhirnya muncul juga berbagai jasa crowdfunding di Indonesia seperti, www.crowde.co, www.kitabisa.com, www.gandengtangan.org, ww.wujudkan.com dan sebagainya.

Paul Schulte dan Gavin Liu dalam penelitiannya yang disampaikan dalam artikelnya yang berjudul Fintech is Merging with IoT and AI to Challenge Banks: How Entrenched Interested Can Prepare, mereka menuliskan: "A company like Alibaba can grow rapidly in e-commerce and serve as the back-bone of banks through profitable offerings from its cloud business, where billions of digital data on customer are stored. Ant Financial can have a value of $\$ 60$ billions and offer credit ratings on 800 million people and 20 million small and medium sized enterprises (SMEs), challenging traditional ratings agencies". (Paul Schulte and Gavin Liu 2018). 
Dari observasi lapangan dan penjelasan di atas dapat kami ringkas permasalahan yang terjadi terkait dengan pemanfaatan teknologi adalah kurang mengenalnya pemanfaatan teknologi untuk berwirausaha serta bagaimana cara untuk berwirausaha dengan memanfaatkan teknologi.

Adapun tujuan dari pengabdian kepada masyarakat ini adalah untuk memberikan pemahaman kepada masyarakat tentang pemanfaat teknologi sebagai instrumen penting bagi masyarakat yang berwirausaha untuk memperbaiki menuju keluarga sejahtera, sehingga terbentuklah kegiatan pengabdian kepada masyarakat.

\section{METODE}

Kegiatan pengabdian kepada masyarakat ini mengusung tema "Pemanfaatan Teknologi Untuk Mendukung Kesejahteraan Keluarga Untuk Berwirausaha" dilaksanakan di aula kantor Desa Kp. Sawah 003/004 desa Pamegarsari Parung, Bogor Jawa Barat. Dilaksanakan selama satu hari pada tanggal 11 Oktober 2019. Pengabdian Kepada Masyarakat ini ditujukan kepada Ibu Rumah Tangga yang berjumlah 60 orang yang terdiri dari Ibu-ibu Rumah Tangga dan Perangkat Desa.

Kegiatan Pengabdian Kepada Masyarakat dilakukan melalui kegiatan penyuluhan dan persentasi materi tentang pemanfaatan teknologi untuk Ibu rumah tangga. Pemaparan materi di berikan oleh Ibu Luh Nadi, S.E.,M.M., materi yang disampaikan oleh narasumber diawali dengan penjelasan arti dari teknologi, memberikan wawasan tentang pemanfaatan teknologi untuk Ibu rumah tangga, memberikan pemahaman akan manfaatnya teknologi kini untuk berwirausaha, menanamkan kesadaran kepada para ibu rumah tangga untuk berwirausaha dengan teknologi dan memberikan informasi mengenai cara berwirausaha secara online.

Memberikan pemahaman, motivasi dan semangat kepada peserta untuk memperbaiki kondisi keuangan keluarga melalui berwirausaha dengan memanfaatkan teknologi yang baik dan terarah.

Kegiatan lebih rinci tertuang dalam tabel dibawah ini:

\begin{tabular}{|l|l|l|}
\hline Program & Metode & Partisipasi \\
\hline $\begin{array}{l}\text { Pemanfaatan } \\
\text { teknologi untuk } \\
\text { Ibu Rumah } \\
\text { Tangga }\end{array}$ & Persentase & $\begin{array}{l}\text { Peserta kegiatan } \\
\text { mendengarkan } \\
\text { pemaparan } \\
\text { materi yang } \\
\text { disampaikan } \\
\text { oleh narasumber }\end{array}$ \\
\hline $\begin{array}{l}\text { Pemanfaatan } \\
\text { teknologi untuk } \\
\text { Ibumah }\end{array}$ & Tanya Jawab & $\begin{array}{l}\text { Peserta kegiatan } \\
\text { melakukan } \\
\text { Tangga }\end{array}$ \\
& & $\begin{array}{l}\text { tanya jawab } \\
\text { kepada } \\
\text { narasumber } \\
\text { berkaitan } \\
\text { dengan materi }\end{array}$ \\
\hline
\end{tabular}




\begin{tabular}{|l|l|l|}
\hline & yang \\
disampaikan \\
\end{tabular}

\section{HASIL DAN PEMBAHASAN}

Kegiatan pengabdian pada masyarakat ini akan dilaksanakan di desa Pamegarsari Parung, Bogor, Jawa Barat. Kegiatan Pengabdian Kepada Masyarakat ini diikuti oleh 60 Ibu-ibu Rumah Tangga pada tanggal 11 Oktober 2019 pada pukul 13.30 sampai 16.30 WIB. Secara umum kegiatan pelatihan ini berjalan dengan lancar dan antusias Ibuibu Rumah Tangga untuk mengikuti kegiatan tersebut sangat tinggi. Karena mereka ingin mengetahui secara mendalam dan meluas bagaimana cara memanfaat teknologi canggih untuk dapat berwirausaha dengan mudah dan sukses sehingga dapat memperbaikan taraf hidup yang lebih baik lagi. Antusias Ibu-ibu Rumah Tangga dalam penyuluhan dapat dilihat pada gambar berikut ini :

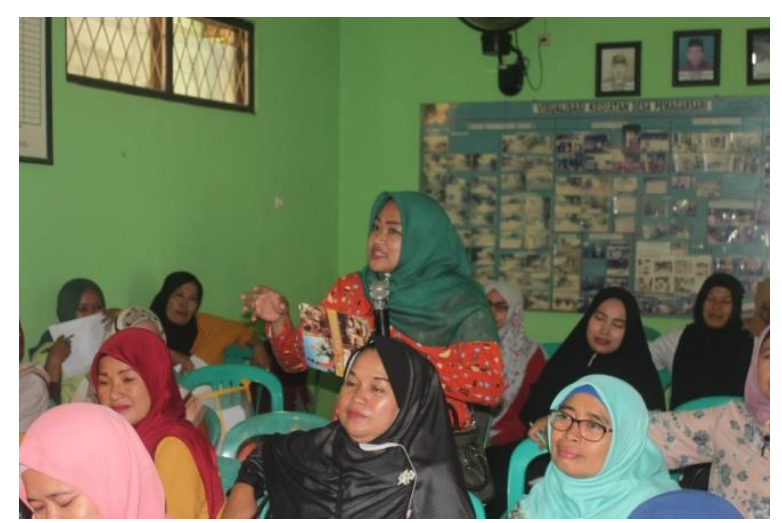

Gambar 1

Antusias peserta dalam tanya jawab

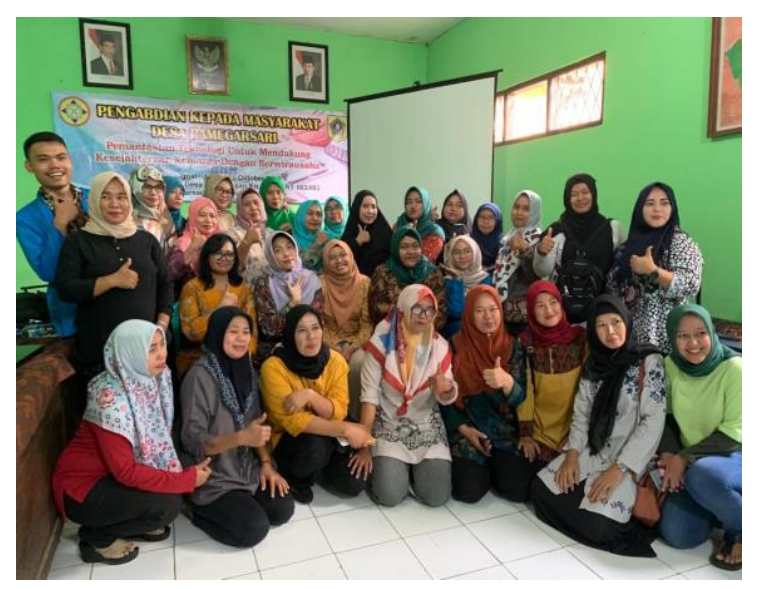

Gambar 2

Antusias para peserta penyuluhan

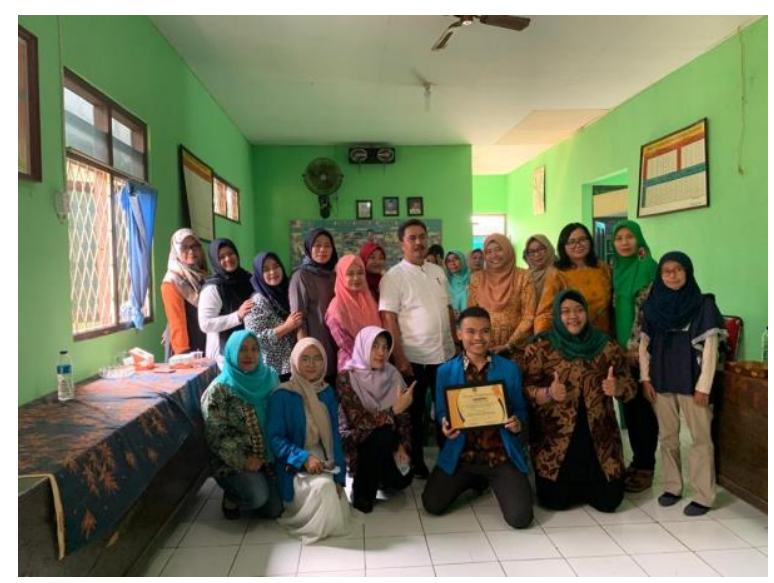

Gambar 4

Antusias peserta dan perangkat desa

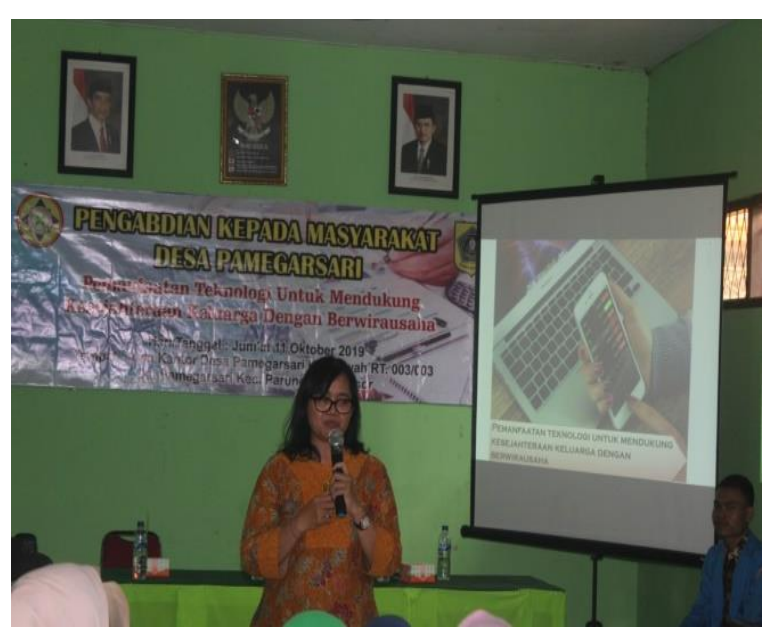

Gambar 3

Pemaparan dan persentasikan materi 
Materi yang di sampaikan dalam kegiatan pengabdian kepada masyarakat ini, adalah memberikan wawasan tentang pemanfaatan teknologi untuk Ibu rumah tangga, memberikan pemahaman akan bermanfaatnya teknologi kini untuk berwirausaha, menanamkan kesadaran kepada para ibu rumah tangga untuk berwirausaha dengan teknologi, memberikan informasi mengenai cara berwirausaha secara online, memberikan motivasi dan semangat kepada peserta untuk memperbaiki kondisi keuangan keluarga melalui berwirausaha dengan memanfaatkan tehnologi yang baik dan terarah.

Dengan diberikan pemahaman di atas para ibu-ibu lebih tahu jelas manfaat teknologi untuk mereka berwirausaha. Dalam sebuah forum tanya jawab diungkapkan bahwa setelah mereka mendengarkan penjelasan dari narasumber ibu-ibu rumah tangga sangat termotivasi untuk mengenal lebih jauh mengenai kemajuan dan manfaat teknologi untuk berwirausaha, dan dari forum tanya jawab tersebut mereka meminta kepada narasumber kiat-kiat agar Ibu Rumah Tangga di Desa Pamegar Sari - Bogor dapat berwirausaha dengan lancar dan sukses.

Materi yang disampaikan pada saat penyuluhan tentang pentingnya teknologi untuk Ibu- ibu Rumah Tagga dengan tema “ Pemanfaatan Teknologi untuk Mendukung
Kesejahteraan keluarga dengan berwirausaan yaitu :

1 Memberikan wawasan tentang pemanfaatan teknologi untuk ibu rumah tangga

2. Memberikan pemahaman akan bermanfaatnya tehnologi kini untuk berwirausaha.

3. Menanamkan kesadaran kepada para ibu rumah tangga untuk berwirausaha dengan teknologi.

4. Memberikan informasi mengenai cara berwirausaha secara online.

5. Memberikan motivasi dan semangat kepada peserta untuk memperbaiki kondisi keuangan keluarga melalui berwirausaha dengan memanfaatkan tehnologi yang baik dan terarah.

Setelah dilakukan penyuluhan tentang pemanfaatan teknologi untuk Ibu Rumah Tangga dilakukan sesi tanya jawab mengenai pemanfaatan teknologi dan berwirausaha. Oleh peserta dan narasumber, kegiatan pengabdian kepada masyarakat ini juga diselingi dengan kegiatan games. Permainan berupa pertanyaan yang diajukan oleh narasumber dan peserta yang bisa menjawab pertanyaan denga benar diberikan doorprize yang menarik.

Setelah dilakukan pemaparan materi oleh narasumber dan sesi tanya jawab mengenai Pemanfaatan teknologi untuk mendukung kesejahteraan keluarga dengan teknologi 
kami juga mewawancarai langsung ibu-ibu rumah tangga untuk menanyakan seberapa tertariknya mereka terhadap kegiatan ini, dan mereka memberikan jawaban bahwa mereka sangat senang sekali dengan kegiatan ini, karena bermanfaat sekali untuk tahu bahwa teknologi sangat dapat membantu mereka dalam menjalankan bisnis melalui mediamedia online. Kegiatan dilanjutkan dengan pemberian plakat dan piagam dari pihak Universitas Pamulang kepada perangkat Desa di desa Pamegarsari Parung, Bogor, Jawa Barat.

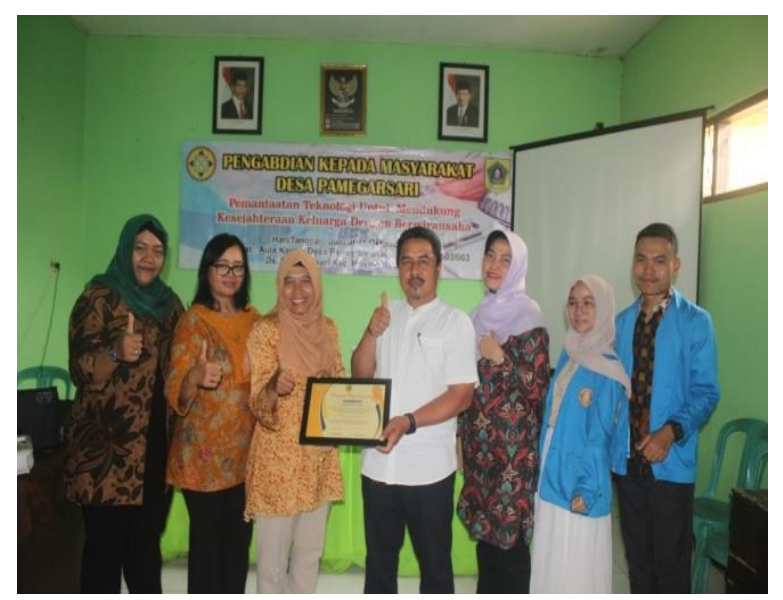

Gambar 4.

Pemberian Plakat dan Piagam kepada perangkat desa

Kegiatan pengabdian ini dinilai sangat bermanfaat sekali dengan kondisi Ibu-ibu Rumah Tangga Desa Pemegarsari yang memang masih sangat membutuhkan informasi mengenai teknologi dan media sosial dalam membantu berwirausaha. Pada pelaksanaan kegiatan ini, tim dosen tidak mengalami hambatan yang berarti, karena dari awal sudah melakukan survey kepada
Ibu-Ibu Rumah Tangga dan perangkat Desa sudah sudah menyambut baik proposal kegiatan yang diajukan,. Karena Desa Pamegarsari Parung ini belum pernah diadakan kegiatan semacam ini.

\section{KESIMPULAN}

Kurangnya wawasan akan pentingnya pemanfaatan teknologi dalam keluarga menyebabkan banyaknya para ibu rumah tangga melakukan pengelolaan keuangan dengan berwirausaha tanpa mengikuti cara yang kurang tepat, yang pada akhirnya usaha rumah tangga tersebut cepat tutup. Untuk itu sasaran kami adalah membantu ibu rumah tangga untuk lebih aktif lagi menggunakan tehnologi terutama aplikasi penjualan agar laba tanpa harus melakukan pemasaran yang kurang tepat. Sepanjang tahun 2017, setidaknya muncul lebih dari 40 bisnis fintech baru yang mencoba peruntungan di lanskap keuangan Indonesia bersama dengan 140-an startup lain yang telah berdiri sebelumnya. Industri fintech Indonesia memang menjadi salah satu primadona yang menarik perhatian begitu besar dari para pelaku industri keuangan. Investasi pada startup fintech mulai banyak diminati, bahkan beberapa startup berhasil mendapatkan investasi seri A di tahun ini. Sektor-sektor fintechmulai berkembang dan produk-produk baru banyak diluncurkan. Sementara itu, Kementerian Koperasi dan 
Usaha Kecil Menengah (Kemenkop UKM) melansir sebanyak 3,79 juta usaha mikro, kecil, dan menengah (UMKM) sudah memanfaatkan platform online dalam memasarkan produknya. Jumlah ini berkisar 8 persen dari total pelaku UMKM yang ada di Indonesia, yakni 59,2 juta.

Masalah sumber pembiayaan merupakan masalah klasik yang menjadi penghambat pertumbuhan UMKM yang tidak mendapat fasilitas pembiayaan dari sektor perbankan. Kurangnya sumber dana menjadikan UMKM tidak dapat mengembangkan inovasi untuk meningkatkan produksinya. Namun demikian pesatnya pertumbuhan bisnis pembiayaan FinTech seperti peer-to-peer lending sekarang ini bisa menjadi alternatif lain bagi para pencari dana pinjaman. Peerto-peer lending merupakan bisnis pembiayaan yang menyasar sektor pasar menengah ke bawah.

Perkembangan teknologi yang tidak terbatas di era digital sekarang ini, semakin lengkap dengan hadirnya fintech. Istilah fintech merupakan sebuah layanan keuangan dengan menggunakan basis teknologi yang tentunya akan semakin memudahkan transaksi yang kita lakukan dimana saja dan kapan saja. Model keuangan baru ini, fintech dimulai pertama kali pada tahun 2004 oleh Zopa, yaitu institusi keuangan di Inggris yang menjalankan jasa peminjaman uang. Kemudian dilanjutkan dengan Bitcoin yang digagas oleh Satoshi Nakamoto pada tahun 2008.

\section{Saran}

Pelaksanaan kegiatan PKM ini diharapkan tetap dilakukan secara rutin untuk membantu para ibu-ibu peserta PKM memperoleh kondisi keuangan keluarga yang sehat. Beberapa saran yang disampaikan adalah sebagai berikut:

1. Kegiatan yang sudah ada supaya tetap dipertahankan dan ditingkatkan lagi dalam melaksanakannya melalui program pendampingan dan mentoring berkelanjutan dalam melakukan berwirausaha secara tepat.

2. Melakukan kegiatan PKM dengan topik lanjutan yang berkaitan dengan pemanfaatan teknologi dengan berwirausaha melalui pengembangan bisnis rumah tangga.

\section{REFERENSI}

Schulte Paul \& Liu, Gavin. (2018). FinTech is Merging with IoT and AI to Challenge Banks; How Entrenched Interest Can Prepare. The Journal of Alternative Investments JAI 2017, doi; https://doi.org/10.3905/jai.2018.20.3.041 
http://jai.iijournals.com/content/20/3/41 diakses tanggal 4 Juli 2018.

www.crowde.com www.kitabisa.com

www.gandengtangan.org

www.wujudkan.com 